\title{
STRATEGI PENGEMBANGAN AGROINDUSTRI STROBERI
}

\author{
Oleh \\ CICI AULIA PERMATA BUNDA \\ Fakultas Pertanian Universitas Galuh Ciamis \\ e-mail: ciciauliapb@gmail.com
}

\begin{abstract}
Abstrak
Penelitian ini bertujuan untuk mengetahui faktor-faktor yang menjadi kekuatan, kelemahan, peluang dan ancaman bagi agroindustri stroberi "Kharisma" serta mengetahui strategi yang paling tepat dalam upaya pengembangan agroindustri stroberi "Kharisma" Desa Alam Endah Kecamatan Rancabali Kabupaten Bandung. Metode yang digunakan dalam penelitian ini adalah studi kasus pada agroindustri stroberi "Kharisma" di Desa Alam Endah Kecamatan Rancabali Kabupaten Bandung. Alat analisis yang digunakan adalah analisis SWOT (Strengths, Weaknesses, Opportunities dan Threats) dan QSPM (Quantitative StrategicPlanning Matrix).Hasil analisis dan pembahasan menunjukan bahwa faktor-faktor yang menjadi kekuatan bagi agroindustri stroberi Kharisma yaitu kualitas bahan baku yang bagus, produk yang dihasilkan memiliki keunggulan rasa dan tanpa bahan pengawet, sumber daya finansial (modal) sepenuhnya berasal dari perusahaan (equity capital), penyediaan bahan baku yang efektif dan efisien serta proses produksi masih sederhana sehingga rasa lebih khas. Faktor-faktor yang menjadi kelemahan bagi agroindustri stroberi Kharisma yaitu belum memiliki outlet penjualan secara khusus, promosi belum dilakukan, keterbatasan suplai tenaga kerja terampil, lokasi usaha tidak terletak di jalan utama, ketersediaan sarana produksi belum optimal dan kapasitas produksi masih kecil.Faktor-faktor yang menjadi peluang bagi agroindustri stroberi Kharisma yaitu pertumbuhan objek wisata yang cukup pesat, selera konsumen yang beragam, pemasok yang mampu menjamin ketersediaan bahan baku, adanya dukungan kebijakan atau program pemerintah bagi pengembangan agroindustri, keberadaan agen yang loyal dan budaya atau kebiasaan wisatawan atau masyarakat membeli oleh-oleh khas daerah. Faktor-faktor yang menjadi ancaman bagi agroindustri stroberi Kharisma yaitu pesaing produk agroindustri sejenis, kenaikan biaya produksi dan faktor musim yang mempengaruhi kualitas buah stroberi sebagai bahan baku.Strategi yang paling tepat dalam upaya pengembangan agroindustri stroberi Kharisma adalah strategi S-O (StrengthsOpportunities)yaitu dengan meningkatkan volume penjualan melalui optimalisasi potensi pasar wisata dan pengembangan produk.
\end{abstract}

Kata kunci: strategi pengembangan, SWOT, agroindustri stroberi

\section{PENDAHULUAN}

Stroberi merupakan salah satu komoditas hortikultura yang memiliki nilai ekonomi tinggi dan pangsa pasar yang baik. Kabupaten Bandung merupakan salah satu daerah yang mempunyai potensi dalam pengembangan stroberi di wilayah Provinsi Jawa Barat. Berdasarkan data dari Badan Pusat Statistik Kabupaten Bandung (2011).Produksi stroberi Kabupaten Bandung tahun 2010 mencapai 347 ton dan desa yang memproduksi stroberi terbanyak yaitu Desa Alam Endah Kecamatan Rancabali dengan nilai produksi stroberi mencapai 250 ton.

Pada umumnya stroberi di Desa Alam Endah dibudidayakan untuk dijual dalam bentuk buah segar. Stroberi dapat dipanen setelah empat bulan setelah tanam. Setelah dipanen buah yang rusak dipisahkan dari buah yang baik. Buah disortir berdasarkan ukuran, bentuk, warna dan kemulusan permukaan buah. Buah kualitas baik di grading berdasarkan ukuran buah.Buah stroberi yang yang lecet, cacat atau ukurannya sangat kecil tidak sesuai ke dalam kelas grading biasanya memiliki nilai jual yang rendah apabila dijual dalam bentuk buah segar.Selain itu buah stroberi termasuk buah yang sangat sensitif dan cepat rusak.

Melihat karakteristik buah stroberi seperti yang diuraikan di atas maka dilakukan berbagai upaya untuk meningkatkan daya simpan dan nilai jual stroberi terutama buah yang lecet, cacat serta yang ukurannya sangat kecil (tidak masuk ke dalam kelas grading). Salah satu solusi yang dilakukan untuk memecahkan permasalahan tersebut adalah mengolah buah stroberi menjadi berbagai produk olahan seperti dodol, selai, dan sirup, sebagaimana yang dilakukan agroindustri stroberi "Kharisma". di Desa Alamendah Kecamatan Rancabali 


\section{AIMBAR \\ Agribisnis}

ISSN 2460-4321

Volume 1・Nomor 2・Januari 2016

Kabupaten Bandung. Saat ini, produk tersebut sudah menjadi ciri khas buah tangan daerah agrowisata Ciwidey-Rancabali yang tetap diminati sehingga permintaan terhadap produk tersebut kian meningkat.

Namun nampaknya permintaan yang tinggi terhadap produk olahan stroberi, tidak hanya direspon oleh satu agroindustri saja, akan tetapi juga oleh pihak lain yang ingin mendapatkan keuntungan dari proses pengolahan hasil pertanian sehingga munculah berbagai agroindustri sejenis maupun agroindustri lain yang mana mereka berusaha menarik perhatian konsumen.

Agar suatu agroindustri dapat tetap bertahan ditengah persaingan pasar yang makin ketat, maka diperlukan adanya strategi yang tepat karena dengan adanya strategi dapat memberikan arah dalam upaya pengembangan agroindustri stroberi "Kharisma" yang dipengaruhi oleh berbagai faktor baik faktor yang menjadi kekuatan, kelemahan, peluang maupun ancaman.

Berdasarkan latar belakang tersebut peneliti tertarik untuk meneliti : (1) Faktorfaktor apa saja yang menjadi kekuatan, kelemahan, peluang dan ancaman bagi agroindustri stroberi "Kharisma" Desa Alam Endah Kecamatan Rancabali Kabupaten Bandung. (2) Bagaimana strategi yang paling tepat dalam upaya pengembangan agroindustri stroberi "Kharisma" Desa Alam Endah Kecamatan Rancabali Kabupaten Bandung?. Tujuan dari penelitian ini adalah (1) Mengidentifikasikan faktor-faktor yang menjadi kekuatan, kelemahan, peluang dan ancaman bagi agroindustri stroberi "Kharisma" Desa Alam Endah Kecamatan Rancabali Kabupaten Bandung (2) Menentukan strategi yang tepat dalam upaya pengembangan agroindustri stroberi "Kharisma" Desa Alam Endah Kecamatan Rancabali Kabupaten Bandung.

\section{TINJAUAN PUSTAKA}

\section{Stroberi}

Stroberi berasal dari pegunungan Chili, Amerika Utara, di Indonesia yang termasuk negara tropis stroberi sudah banyak dibudidayakan di daerah dataran tinggi, yaitu sekitar 1.000-1.500 meter di atas permukaan laut. Tanaman stroberi membutuhkan lingkungan tumbuh bersuhu dingin (sejuk) dan lembab. Meskipun demikian, tanaman stroberi dapat tumbuh dan berproduksi dengan baik pada daerah-daerah yang mempunyai kondisi iklim sebagai berikut (Rahmat Rukmana, 1998):

- Suhu udara optimum antara $17^{\circ} \mathrm{C}-20^{\circ} \mathrm{C}$.

- Kelembaban udara (rh) $80 \%-90 \%$.

- Penyinaran matahari 8-10 jam per hari.

- Curah hujan berkisar antara $600-700 \mathrm{~mm}$ per tahun.

Buah stroberi termasuk buah yang sangat sensitif dan cepat rusak. Buah stroberi hanya mampu bertahan empat hari jika dilakukan penyimpanan di lemari pendingin $0-1{ }^{\circ} \mathrm{C}$. Sifat buah stroberi mudah rusak (perishable). Hal ini disebabkan stroberi merupakan buah yang mempunyai tekstur yang lembut dan tidak mempunyai serat sehingga relatif sensitif terhadap gesekan fisik, suhu, dan sinar matahari (Supriatin Budiman dan Desi Saraswati, 2010).

\section{Agroindustri}

Agroindustri adalah industri yang berbahan baku utama dari produk pertanian. Studi agroindustri pada konteks ini adalah menekankan pada food processing management dalam suatu agroindustri produk olahan yang bahan baku utamanya adalah produk pertanian (Soekartawi, 2001).

Menurut Moehar Daniel (2002) mengistilahkan agroindustri dengan istilah subsistem agribisnis hilir, yakni industriindustri yang mengolah komoditi pertanian primer menjadi olahan seperti industri makanan atau minuman, industri pakan, industri barang serat-serat alam, industri farmasi, industri bioenergi dan lain-lain.

\section{Strategi Pengembangan Agroindustri}

Strategi didefinisikan sebagai alat untuk mencapai tujuan perusahaan dalam kaitannya dengan tujuan jangka panjang, program tindak lanjut, serta prioritas alokasi sumber daya (Chandler, 1962) dalam Freddy Rangkuti (2009).

Dengan demikian, strategi adalah suatu pola atau perencanaan yang mampu mengintegrasikan sasaran, kebijakan, dan tindakan-tindakan organisasi secara kohesi. Sejalan dengan definisi agroindustri yang telah dijelaskan sebelumnya, maka pengembangan 


\section{Strategi Pengembangan Agroindustri Stroberi CICI AULIA PERMATA BUNDA}

agroindustri merupakan segala bentuk pengusahaan yang dilakukan ke arah yang lebih baik dari sebelumnya.

Berdasarkan uraian tersebut, maka strategi pengembangan agroindustri adalah suatu pola pengembangan agroindustri yang mengintegrasikan sasaran, kebijakan, dan tindakan-tindakan organisasi usaha secara terpadu sehingga menjadi lebih baik, dalam arti terciptanya nilai tambah dari keadaan sebelumnya (Supriyati dan Suryani E, 2006).

Menurut Soekartawi (2001) terdapat faktor-faktor yang mempengaruhi berhasilnya pengembangan agroindustri yaitu:

1. Faktor yang berkaitan dengan aspek produksi khususnya perlunya memperhatikan ketersediaan produk pertanian yang dipakai sebagai bahan baku, baik dalam kuantitasnya, kualitasnya maupun kontinuitasnya. Secara kuantitas, bahan baku harus tersedia secara cukup setiap saat manakala bahan baku tersebut diperlukan. Ini tidak mudah karena produk pertanian yang dipakai sebagai bahan baku tersebut adalah bersifat musiman. Dilihat dari sisi kualitas, maka bahan baku seyogyanya harus tersedia secara tepat. Bila hal ini tidak terpenuhi, maka hal tersebut akan berakibat pada menurunnya kualitas produk agroindustri yang kemudian secara kuantitas, maka bahan baku harus tersedia secara kontinyu sepanjang tahun, karena proses produksi terus berjalan tidak peduli apakah saat itu musim hujan atau musim kemarau. Untuk itu ketersediaan bahan baku ini harus diperhatikan baik dalam jangka pendek, menengah maupun jangka panjang.

2. Faktor yang berkaitan dengan aspek konsumsi khususnya bersamaan dengan berkembangnya dinamika permintaan pasar, baik pasar individu atau rumah tangga ataupun pasar institusi, baik pasar yang ada di dalam negeri maupun pasar luar negeri. Proposisi ini menjadi penting bersamaan dengan perubahan yang besar pada preferensi konsumen terhadap produkproduk agroindustri.

3. Faktor yang berkaitan dengan aspek distribusi khususnya bersamaan dengan berkembangnya dinamika para pesaing (competitors) perusahaan agroindustri yang menyalurkan produksi sampai ke tangan konsumen, baik konsumen yang ada di dalam negeri maupun yang ada di luar negeri. Proposisi ini menjadi penting karena seringnya ditemukan berdirinya perusahaan agroindustri yang kurang memperhatikan kekuatan dan kelemahan para pesaingnya, sehingga dengan demikian perusahaan tersebut kurang dapat berkembang seperti yang diharapkan.

4. Faktor yang berkaitan dengan kondisi internal perusahaan. Faktor ini berkaitan dengan kondisi kualitas dan sumber daya manusia dalam menjalankan perusahaan, khususnya dalam bidang kemampuan manajerialnya. Faktor ini juga berkaitan dengan perlunya memperhatikan dampak dari perubahan global khususnya pengaruh informasi dan teknologi yang secara langsung ataupun tidak langsung berpengaruh pada masa depan perusahaan agroindustri tersebut.

Oleh karena itu, maka perlu diperhatikan dimana kekuatan (strength) yang dimiliki perusahaan, kelemahan (weaknesses) yang dihadapi, peluang (opportunities) yang seharusnya diraih dan ancaman (threat) yang mungkin berpengaruh terhadap masa depan perusahaan agroindustri tersebut (Soekartawi, 2001).

Bila empat faktor ini benar dan dapat berjalan seperti yang diharapkan, maka agroindustri akan tumbuh dan berkembang sehingga akhirnya ia mampu meningkatkan perolehan devisa, menyerap banyak tenaga kerja, meningkatkan pendapatan para pelaku agribisnis dan meningkatkan tumbuhnya industri yang lain (Soekartawi, 2001).

\section{METODE PENELITIAN}

Metode penelitian yang digunakan dalam penelitian ini adalah studi kasus. Menurut Moehar Daniel (2003) studi kasus adalah penelitian yang sifatnya lebih terarah atau terfokus pada sifat tertentu yang tidak berlaku umum, biasanya dibatasi oleh kasus, lokasi, tempat tertentu dan waktu tertentu. Penelitian dilaksanakan di agroindustri stroberi Kharisma, Desa Alam Endah Kecamatan Rancabali Kabupaten Bandung. Pemilihan lokasi tersebut dilakukan secara sengaja (purposive) dengan pertimbangan bahwa agroindustri tersebut merupakan agroindustri yang memproduksi olahan stroberi secara kontinyu di sentra 


\section{AIMBAR \\ Agribisnis}

ISSN 2460-4321

Volume 1・ Nomor 2 • Januari 2016

produksi stroberi Desa Alam Endah Kecamatan Rancabali Kabupaten Bandung.

Teknik penentuan responden yang digunakan adalah metode purposive sampling, yaitu dilakukan dengan sengaja memilih responden yang diwawancara dengan pertimbangan bahwa responden yang dimaksud memiliki kapasitas dan kemampuan dalam rangka perumusan strategi pengembangan usaha serta memiliki pengetahuan yang cukup tentang agroindustri stroberi Kharisma. Responden yang dalam penelitian ini terdiri dari delapan orang yaitu pemilik agroindustri stroberi Kharisma, wakil dari Dinas Pertanian Kabupaten Bandung, Dinas Koperasi Industri dan Perdagangan Kabupaten Bandung, Pemasok bahan baku stroberi (petani), pemasok bahan baku stroberi (pedagang besar), pemasok bahan baku lainnya, agen dan konsumen produk olahan stroberi yang diproduksi oleh agroindustri stroberi Kharisma.

Analisisstrategi Pengembangan agroindustri stroberi Kharisma dianalisis secara deskriptif berdasarkan faktor lingkungan internal dan eksternal. Focus Group Discussion (FGD) dilakukan untuk mengidentifikasikan beberapa faktor lingkungan (internal dan eksternal) serta untuk mengkolaborasikan faktor-faktor tersebut menjadi strategi yang tepat untuk dilakukan dalam pengembangan agroindustri stroberi "Kharisma" Desa Alam Endah Kecamatan Rancabali Kabupaten Bandung. Focus Group Discussion (FGD) dilakukan dengan komprehensif dan melibatkan seluruh pihak yang terkait dengan usaha agroindustri stroberi "Kharisma" sehingga terbentuk infomasi yang telah mewakili seluruh kepentingan pihak terkait.

Setelah teridentifikasi faktor-faktor lingkungan internal dan eksternal maka Focus Group Discussion (FGD) selanjutnya difokuskan pada analisis faktor-faktor lingkungan (internal dan eksternal) tersebut menggunakan analisis SWOT (Strengths Weaknesses Opportunities Threats). Analisis SWOT didasarkan pada asumsi bahwa strategi yang efektif akan memaksimalkan faktor-faktor lingkungan yang menjadi kekuatan (strengths) danpeluang (opportunities) disertai dengan meminimalkan kelemahan (weaknesses) dan ancaman (threats). Selanjutnya untuk menetapkan strategi pengembangan usaha yang diprioritaskan dilakukan melalui pendekatan analisis QSPM (Quantitative Strategic Planning Matrix). Penentuan prioritas strategi pengembangan ini bertujuan menunjukan strategi alternatif mana yang paling baik untuk dipilih.

\section{Analisis Faktor Internal IFAS}

Analisis internal dilakukan untuk mengetahui faktor-faktor kekuatan perusahaan yang dapat dimaksimalkan peranannya dan faktor-faktor kelemahan perusahaan yang harus segera diatasi. Untuk merumuskan faktor-faktor strategi internal tersebut disusun dengan menggunakan matriks IFAS (Internal Factors Analisys Summary). Matriks IFAS nilai yang diperoleh mengidentifikasikan seberapa besar kekuatan dan kelemahan yang dapat mempengaruhi kelangsungan usaha dari perusahaan dan respon perusahaan terhadap faktor-faktor internal tersebut.

\section{Analisis Faktor Eksternal EFAS}

Analisis internal dilakukan untuk mengetahui faktor-faktor peluang perusahaan yang dapat dimaksimalkan peranannya dan faktor-faktor ancaman perusahaan yang harus dihindari. Untuk merumuskan faktor-faktor strategi ekternal tersebut disusun dengan menggunakan matriks EFAS (Eksternal Factors Analisys Summary). matriks EFAS nilai yang diperoleh mengidentifikasikan seberapa besar peluang dan ancaman yang dapat mempengaruhi kelangsungan perusahaan dan respon perusahaan terhadapan faktor eksternal tersebut.

\section{Analisis Matriks Internal-Eksternal}

Matriks ini bertujuan untuk mengetahui posisi agroindustri stroberi dan dapat mempermudah dalam penentuan alternatif strategi serta pengambilan keputusan prioritas strategi pengembangan. Matriks Internal-Eksternal menempatkan parameter kekuatan internal dan pengaruh eksternal 


\section{Strategi Pengembangan Agroindustri Stroberi CICI AULIA PERMATA BUNDA}

yang dihadapi dengan tujuan untuk memperoleh strategi di tingkat yang lebih detail sebelum menentukan alternatif strategi. Matriks ini dibagi menjadi tiga bagian utama dan mempunyai dampak strategi yang berbeda (Tabel 1).

Tabel 1. Matriks Internal-Eksternal Total Skor IFAS

\begin{tabular}{|c|c|c|c|c|c|}
\hline \multirow{3}{*}{$\begin{array}{l}\text { Total Skor } \\
\text { EFAS }\end{array}$} & \multirow[b]{2}{*}{ Tinggi } & 4 & Kuat & 3 Rata-rata 2 & Lemah \\
\hline & & 3 & I & II & III \\
\hline & Sedang & & IV & V & VI \\
\hline & Rendah & & VII & VIII & IX \\
\hline
\end{tabular}

Keterangan:

a. Jika pertemuan antara titik total dan skor IFAS dan EFAS ada di sel I, II, atau IV artinya agroindustri stroberi "Kharisma" dapat disebut tumbuh dan bina, strategi yang tepat adalah strategi intensif (pengembangan kuantitas dan kualitas produk) atau melakukan integratif.

b. Jika pertemuan antara titik total dan skor IFAS dan EFAS ada di sel III, V atau VII artinya agroindustri stroberi "Kharisma" dapat dikelola dengan strategi mempertahankan dan memelihara keadaan yang sudah ada.

c. Jika pertemuan antara titik total dan skor IFAS dan EFAS ada di sel VI, VIII, atau IX artinya agroindustri stroberi "Kharisma" harus melakukan deinvestasi.

\section{Analisis Matriks SWOT}

Analisis strategi pengembangan menggunakan alat analisis SWOT yaitu analisis matriks SWOT. Matriks ini menggambarkan tentang peluang dan ancaman eksternal yang dihadapi dan disesuaikan dengan kekuatan dan kelemahan yang dimilikinya. Freddy Rangkuti (2000) mengemukakan bahwa matriks SWOT ini dapat menggambarkan secara jelas bagaimana peluang dan ancaman eksternal yang dihadapi kelompok dapat disesuaikan dengan kekuatan dan kelemahan yang dimilikinya. Matriks ini dapat menghasilkan empat set kemungkinan alternatif strategi pengembangan (Tabel 2).
Tabel 2. Matriks SWOT

\begin{tabular}{|c|c|c|}
\hline TERNAL & $\begin{array}{l}\text { KEKUATAN } \\
\text { (S) }\end{array}$ & $\begin{array}{l}\text { KELEMAHAN } \\
\text { (W) }\end{array}$ \\
\hline PELUANG (O) & $\begin{array}{c}\text { STRATEGI SO } \\
\text { Ciptakan strategi } \\
\text { yang menggunakan } \\
\text { kekuatan untuk } \\
\text { memanfaatkan } \\
\text { peluang }\end{array}$ & $\begin{array}{c}\text { STRATEGI WO } \\
\text { Ciptakan strategi yang } \\
\text { meminimalkan } \\
\text { kelemahan untuk } \\
\text { memanfaatkan peluang }\end{array}$ \\
\hline ANCAMAN (T) & $\begin{array}{c}\text { STRATEGI ST } \\
\text { Ciptakan strategi } \\
\text { yang menggunakan } \\
\text { kekuatan untuk } \\
\text { mengatasi } \\
\text { ancaman } \\
\end{array}$ & $\begin{array}{c}\text { SRTATEGI WT } \\
\text { Ciptakan strategi yang } \\
\text { meminimalkan } \\
\text { kelemahan dan } \\
\text { menghindari ancaman }\end{array}$ \\
\hline
\end{tabular}

\section{Analisis Quantitative Strategic Planning Matrix (QSPM)}

Untuk menetapkan strategi pengembangan usaha yang diprioritaskan dilakukan melalui pendekatan analisis QSPM. Penentuan prioritas strategi pengembangan ini bertujuan untuk menunjukan strategi alternatif mana yang paling baik untuk dipilih.

\section{HASIL DAN PEMBAHASAN}

\section{Identifikasi Faktor Lingkungan Internal}

Kekuatan dan kelemahan merupakan faktor internal yang akan menentukan bagaimana strategi yang tepat dalam pengembangan agroindustri stroberi "Kharisma". Penentuan indikator faktor strategis lingkungan internal hasil dari Focus Group Discussion (FGD) dengan responden dapat diidentifikasi faktor strategis internal yang merupakan kekuatan dan kelemahan dalam pengembangan agroindustri stroberi "Kharisma". Faktor kekuatan dan kelemahan internal yang sudah teridentifikasi dapat dilihat pada Tabel 3.

Tabel 3 Kekuatan dan kelemahan internal pada agroindustri stroberi "Kharisma"

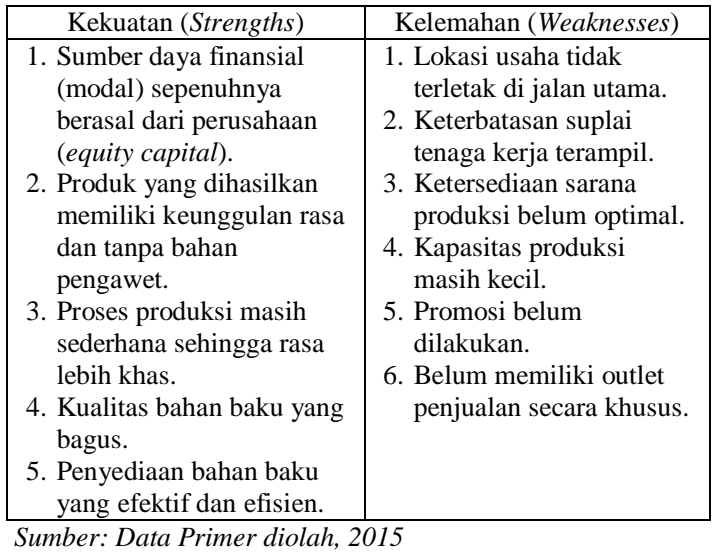




\section{AIMBAR \\ Agribisnis}

ISSN 2460-4321

Volume 1 • Nomor 2 • Januari 2016

\section{Evaluasi Faktor Lingkungan Internal}

Pembobotan dilakukan dengan mengklasifikasikan setiap indikator sesuai dengan kepentingan atau rating, sehingga dapat diperoleh bobot dari masing-masing indikator strategis internal (kekuatan dan kelemahan). Berdasarkan kuisioner pada focus group discussion (FGD), di peroleh nilai skor hasil evaluasi faktor lingkungan internal sebagaimana tercantum dalam matriks IFAS (Tabel 4).

Pada Tabel 4 terdapat empat indikator kekuatan yang memberikan pengaruh sangat besar terhadap pengembangan agroindustri stroberi "Kharisma". Respon terhadap indikator-indikator tersebut sangat kuat bagi agroindustri stroberi "Kharisma" (rating 5), yaitu kualitas bahan baku yang bagus $(0,518)$, produk yang dihasilkan memiliki keunggulan rasa dan tanpa bahan pengawet $(0,512)$ dan sumber daya finansial (modal) sepenuhnya berasal dari perusahaan (equity capital) $(0,506)$. Sedangkan dua indikator kekuatan yang memberikan pengaruh besar terhadap pengembangan agroindustri stroberi "Kharisma" (rating 4) yaitu penyediaan bahan baku yang efektif dan efisien $(0,383)$ dan proses produksi masih sederhana sehingga rasa lebih khas $(0,328)$.

Tabel 4. Matriks IFAS (Internal Factor Analysis Summary)

\begin{tabular}{|c|l|c|r|c|}
\hline \multicolumn{2}{|c|}{$\begin{array}{l}\text { Indikator Faktor } \\
\text { Lingkungan Internal }\end{array}$} & Bobot & Rating & Skor \\
\hline \multicolumn{4}{|c|}{ KEKATAN (STRENGTHS) } \\
\hline (A) & $\begin{array}{l}\text { Sumber daya finansial } \\
\text { (modal) sepenuhnya } \\
\text { berasal dari } \\
\text { perusahaan (equity } \\
\text { capital). }\end{array}$ & 0,101 & 5 & 0,506 \\
\hline (B) & $\begin{array}{l}\text { Produk yang } \\
\text { dihasilkan memiliki } \\
\text { keunggulan rasa dan } \\
\text { tanpa bahan pengawet. }\end{array}$ & 0,102 & 5 & 0,512 \\
\hline (C) & $\begin{array}{l}\text { Proses produksi masih } \\
\text { sederhana sehingga } \\
\text { rasa lebih khas. }\end{array}$ & 0,082 & 4 & 0,328 \\
\hline (D) & $\begin{array}{l}\text { Kualitas bahan baku } \\
\text { yang bagus. }\end{array}$ & 0,104 & 5 & 0,518 \\
\hline (E) & $\begin{array}{l}\text { Penyediaan bahan } \\
\text { baku yang efektif dan } \\
\text { efisien. }\end{array}$ & 0,096 & 4 & 0,383 \\
\hline (F) & $\begin{array}{l}\text { Lokasi usaha tidak } \\
\text { terletak di jalan utama. }\end{array}$ & 0,101 & 1 & 0,101 \\
\hline (G) & $\begin{array}{l}\text { Keterbatasan suplai } \\
\text { tenaga kerja terampil. }\end{array}$ & 0,087 & 1 & 0,087 \\
\hline
\end{tabular}

\begin{tabular}{|c|l|r|r|c|}
\hline$(\mathrm{H})$ & $\begin{array}{l}\text { Ketersediaan sarana } \\
\text { produksi belum } \\
\text { optimal. }\end{array}$ & 0,076 & 3 & 0,229 \\
\hline$(\mathrm{I})$ & $\begin{array}{l}\text { Kapasitas Produksi } \\
\text { masih kecil }\end{array}$ & 0,091 & 2 & 0,182 \\
\hline$(\mathrm{J})$ & $\begin{array}{l}\text { Promosi belum } \\
\text { dilakukan. }\end{array}$ & 0,081 & 1 & 0,081 \\
\hline$(\mathrm{K})$ & $\begin{array}{l}\text { Belum memiliki outlet } \\
\text { penjualan secara } \\
\text { khusus. }\end{array}$ & 0,078 & 1 & 0,078 \\
\hline \multicolumn{2}{|c|}{ Jumlah } & 1,000 & & 3,005 \\
\hline
\end{tabular}

Sumber: Data Primer diolah, 2015

Terdapat empat indikator strategis internal yang termasuk ke dalam komponen kelemahan yang memerlukan perhatian khusus adalah belum memiliki outlet penjualan secara khusus $(0,078)$, promosi belum dilakukan $(0,081)$, keterbatasan suplai tenaga kerja terampil $(0,087)$ dan lokasi usaha tidak terletak di jalan utama $(0,101)$. Indikator-indikator tersebut sangat besar pengaruhnya (rating 1) bagi pengembangan agroindustri stroberi "Kharisma". Sedangkan ketersediaan sarana produksi belum optimal $(0,076)$ besar pengaruhnya (rating 2) dan kapasitas produksi masih kecil $(0,091)$ cukup besar pengaruhnya (rating 3) bagi pengembangan agroindustri stroberi "Kharisma".

Total skor yang diperoleh Matriks IFAS yaitu sebesar 3,005. Menunjukkan bahwa faktor lingkungan internal berada pada tingkat kepentingan baik. Kondisi tersebut menggambarkan bahwa agroindustri stroberi "Kharisma" dalam mengendalikan faktor lingkungan internalnya (kekuatan dan kelemahan) sudah baik serta dapat menunjang dalam pengembangan agroindustri stroberi "Kharisma".

\section{Identifiksi Faktor Lingkungan Eksternal}

Peluang dan Ancaman merupakan faktor eksternal yang akan menentukan bagaimana strategi pengembangan agroindustri stroberi "Kharisma" yang terbaik. Penentuan indikator faktor strategis lingkungan eksternal hasil dari Focus Group Discussion (FGD) dengan responden dapat diidentifikasi faktor strategis eksternal yang merupakan peluang dan ancaman dalam pengembangan agroindustri stroberi "Kharisma". Faktor peluang dan ancaman eksternal yang sudah teridentifikasi dapat dilihat pada Tabel 5. 
Tabel 5. Peluang dan Ancaman Eksternal Pada Agroindustri Stroberi "Kharisma"

\begin{tabular}{|c|c|}
\hline $\begin{array}{c}\text { Peluang } \\
\text { (Opportunities) } \\
\end{array}$ & $\begin{array}{c}\text { Ancaman } \\
\text { (Treaths) }\end{array}$ \\
\hline $\begin{array}{l}\text { 1. Adanya dukungan } \\
\text { kebijakan atau program } \\
\text { pemerintah bagi } \\
\text { pengembangan } \\
\text { agroindustri. } \\
\text { 2. Selera konsumen yang } \\
\text { beragam } \\
\text { 3. Keberadaan agen yang } \\
\text { loyal. } \\
\text { 4. Budaya atau kebiasaan } \\
\text { wisatawan membeli } \\
\text { oleh-oleh khas daerah. } \\
\text { 5. Pertumbuhan objek } \\
\text { wisata yang cukup pesat } \\
\text { 6. Pemasok yang mampu } \\
\text { menjamin ketersediaan } \\
\text { bahan baku. }\end{array}$ & $\begin{array}{l}\text { 1. Kenaikan biaya produksi. } \\
\text { 2. Pesaing produk } \\
\text { agroindustri sejenis. } \\
\text { 3. Faktor musim yang } \\
\text { mempengaruhi kualitas } \\
\text { buah stroberi sebagai } \\
\text { bahan baku utama. }\end{array}$ \\
\hline
\end{tabular}

Faktor strategis eksternal merupakan lingkungan yang berada diluar agroindustri stroberi "Kharisma" baik secara langsung maupun tidak langsung mempengaruhi kinerja agroindustri stroberi "Kharisma". Lingkungan ini memberikan peluang bagi agroindustri stroberi "Kharisma" untuk maju atau sebaliknya menjadi ancaman untuk berkembang.

\section{Evaluasi Faktor Lingkungan Eksternal}

Langkah-langkah dalam evaluasi faktor lingkungan eksternal pada dasarnya sama dengan langkah penyusunan evaluasi faktor lingkungan internal, hanya berbeda pada indikator strategis faktor lingkungan dan analisis yang digunakannya. Faktor lingkungan yang digunakan pada evaluasi faktor lingkungan eksternal meliputi peluang (opportunities) dan ancaman (treaths), analisis yang digunakannya adalah Matiks EFAS (Eksternal Factors Analysis Summary).

Pembobotan dilakukan dengan mengklasifikasikan setiap indikator sesuai dengan kepentingan atau rating, sehingga dapat diperoleh bobot dari masing-masing indikator strategis eksternal (peluang dan ancaman). Berdasarkan kuisioner pada Focus Group Discussion, maka diperoleh nilai skor pada evaluasi faktor lingkungan eksternal dapat dilihat pada matriks EFAS (Tabel 6).

Pada Tabel 6 terdapat tiga indikator peluang yang memberikan pengaruh sangat besar terhadap pengembangan agroindustri stroberi "Kharisma" (rating 5) yaitu pertumbuhan objek wisata yang cukup pesat
$(0,564)$, selera konsumen yang beragam $(0,560)$ dan pemasok yang mampu menjamin ketersediaan bahan baku $(0,551)$. Sedangkan adanya dukungan kebijakan atau program pemerintah bagi pengembangan agroindustri $(0,434)$ dan keberadaan agen $(0,438)$ besar pengaruhnya bagi pengembangan agroindustri stroberi "Kharisma". Budaya atau kebiasaan wisatawan atau masyarakat membeli oleh-oleh khas daerah $(0,234)$.

Indikator strategis eksternal yang termasuk ke dalam komponen ancaman yang memerlukan perhatian khusus dan sangat besar pengaruhnya (rating 1) yaitu pesaing produk agroindustri sejenis $(0,138)$. Sedangkan kenaikan biaya produksi $(0,214)$ dan faktor musim yang mempengaruhi kualitas buah stroberi sebagai bahan baku utama $(0,248)$ besar pengaruhnya (rating 2) bagi pengembangan agroindustri stroberi "Kharisma".

Tabel 6. Matriks EFAS

(Eksternal Factor Analysis Summary)

\begin{tabular}{|c|c|c|c|c|}
\hline \multicolumn{2}{|r|}{ Indikator } & Bobot & Rating & Skor \\
\hline \multicolumn{5}{|c|}{ PELUANG (OPPORTUNITIES) } \\
\hline (A) & $\begin{array}{l}\text { Adanya dukungan } \\
\text { kebijakan/program } \\
\text { pemerintah bagi } \\
\text { pengembangan } \\
\text { agroindustri }\end{array}$ & 0,109 & 4 & 0,434 \\
\hline (B) & $\begin{array}{l}\text { Selera konsumen } \\
\text { yang beragam. }\end{array}$ & 0,112 & 5 & 0,560 \\
\hline (C) & $\begin{array}{l}\text { Keberadaan agen } \\
\text { yang loyal. }\end{array}$ & 0,109 & 4 & 0,438 \\
\hline (D) & $\begin{array}{l}\text { Budaya/kebiasaan } \\
\text { wisatawan/ } \\
\text { masyarakat membeli } \\
\text { oleh-oleh khas } \\
\text { daerah. }\end{array}$ & 0,078 & 3 & 0,234 \\
\hline (E) & $\begin{array}{l}\text { Pertumbuhan objek } \\
\text { wisata yang cukup } \\
\text { pesat. }\end{array}$ & 0,113 & 5 & 0,564 \\
\hline (F) & $\begin{array}{l}\text { Pemasok yang } \\
\text { mampu menjamin } \\
\text { ketersediaan bahan } \\
\text { baku. }\end{array}$ & 0,110 & 5 & 0,551 \\
\hline \multicolumn{5}{|c|}{ ANCAMAN } \\
\hline$(\mathrm{G})$ & $\begin{array}{l}\text { Kenaikan } \\
\text { Produksi }\end{array}$ & 0,107 & 2 & 0,214 \\
\hline$(\mathrm{H})$ & $\begin{array}{l}\text { Pesaing produk } \\
\text { agroindustri sejenis. }\end{array}$ & 0,138 & 1 & 0,138 \\
\hline (I) & $\begin{array}{l}\text { Faktor musim yang } \\
\text { mempengaruhi } \\
\text { kualitas buah } \\
\text { stroberi sebagai } \\
\text { bahan baku utama }\end{array}$ & 0,124 & 2 & 0,248 \\
\hline \multicolumn{2}{|r|}{ Jumlah } & 1,000 & & 3,381 \\
\hline
\end{tabular}

Total skor yang diperoleh Matriks EFAS yaitu sebesar 3,381. Menunjukkan bahwa faktor 


\section{AIMBAR \\ Agribisnis}

ISSN 2460-4321

Volume 1・Nomor 2・Januari 2016

lingkungan eksternal berada pada tingkat kepentingan baik. Kondisi tersebut menunjukkan bahwa agroindustri stroberi "Kharisma" dalam mengendalikan faktor eksternalnya (peluang dan ancaman) sudah cukup baik serta dapat menunjang dalam pengembangan agroindustri stroberi "Kharisma".

\section{Analisis Matriks Internal-Eksternal (IE)}

Matriks ini bertujuan untuk mengetahui posisi agroindustri stroberi "Kharisma" dan dapat mempermudah dalam penentuan alternatif strategi serta pengambilan keputusan prioritas strategi pengembangan agroindustri stroberi "Kharisma". Berdasarkan hasil analisis yang telah dilakukan sebelumnya, bahwa total nilai skor pada Matriks IFAS sebesar 3,005. Maka pada Matriks IE dapat digambarkan bahwa usaha agroindustri stroberi "Kharisma" memiliki faktor internal yang berada pada posisi kuat. Selanjutnya total nilai skor pada matriks EFAS sebesar 3,381 artinya respon usaha agroindustri stroberi "Kharisma" terhadap faktor-faktor eksternal yang dihadapinya berada pada posisi kuat.

Tabel 7. Matriks Internal-Eksternal (I-E)

Total Skor IFAS

$\mathbf{3 , 0 0 5}$

\begin{tabular}{|c|c|c|c|}
\hline 4 & Kuat & 3 Rata-rata & Lemah 1 \\
\hline Total Skor 3381 & I & II & III \\
\hline $\begin{array}{lr} & 3 \\
\text { EFAS } & \text { Sedang }\end{array}$ & IV & V & VI \\
\hline Rendah & VII & VIII & IX \\
\hline
\end{tabular}

Total nilai skor pada matriks IFAS dan EFAS tersebut kemudian dipetakan kedalam Matriks IE (Internal-External Matrix), sehingga dapat diketahui posisi usaha agroindustri stroberi "Kharisma" pada saat ini (Tabel 7).

Setelah total nilai skor dari faktor internal dan eksternal dipetakan dalam Matriks IE, maka posisi usaha agroindustri stroberi "Kharisma" saat ini berada pada kuadran I. Selanjutnya dapat dirumuskan alternatif strategi berdasarkan inti strategi yang sesuai dengan posisi usaha agroindustri stroberi "Kharisma".

Berdasarkan Matriks IE posisi tersebut menggambarkan usaha agroindustri stroberi "Kharisma" berada dalam kondisi internal kuat dan respon terhadap faktor lingkungan eksternal yang dihadapinya pada tinggi.Inti strategi pengembangan usaha agroindustri stroberi "Kharisma" yang dapat diimplementasikan dan dikembangkan pada posisi ini adalah strategi intensif (pengembangan kuantitas dan kualitas produk) atau melakukan integratif.

\section{Analisis SWOT}

Selanjutnya adalah menyusun formulasi atau alternatif strategi dilakukan dengan mencocokan indikator-indikator strategis dari kekuatan, kelemahan, peluang dan ancaman dengan menggunakan matriks SWOT.

Hal yang perlu diperhatikan dalam penyusunan alternatif strategi ini adalah kesesuaian dari segala aspek. Aspek-aspek tersebut adalah aspek tingkat kepentingan indikator strategis, berdasarkan hasil evaluasi faktor lingkungan (Matriks IFAS dan EFAS) serta analisis Matriks IE.

Berdasarkan perhitungan terhadap nilai skor dari setiap alternatif strategi, maka dapat diimplementasikan strategi paling dominan yang dimiliki oleh usaha agroindustri stroberi "Kharisma" adalah pada strategi S-O $(5,027)$ (Tabel 8).

\section{Tabel 8. Perhitungan Nilai Skor terhadap Alternatif Strategi.} Sumber: Data Primer diolah, 2015

\begin{tabular}{|c|c|c|}
\hline EFAS IFAS & $\begin{array}{l}\text { Strengths } \\
\text { (S) }\end{array}$ & $\begin{array}{c}\text { Weaknesees } \\
(\mathrm{W})\end{array}$ \\
\hline $\begin{array}{c}\text { Opportunities } \\
\text { (O) }\end{array}$ & $\begin{array}{c}\text { Strategi S-O } \\
2,246+2,781= \\
5,027\end{array}$ & $\begin{array}{l}\text { Strategi W-O } \\
0,759+2,781 \\
\quad=3,540\end{array}$ \\
\hline Treaths (T) & $\begin{array}{c}\text { Strategi S-T } \\
2,246+0,600= \\
2,846\end{array}$ & $\begin{array}{c}\text { Strategi W-T } \\
0,759+0,600= \\
1,359\end{array}$ \\
\hline
\end{tabular}


Tabel 9. Matriks SWOT

\begin{tabular}{|c|c|c|}
\hline $\begin{array}{c}\text { FAKTOR } \\
\text { EKSTERNAL } \\
(\text { EFAS })\end{array}$ & \begin{tabular}{l}
\multicolumn{1}{c}{ KEKUATAN } \\
(STRENGTHS) \\
1. Sumber daya finansial \\
(modal) sepenuhnya berasal \\
dari perusahaan (equity \\
capital). \\
2. Produk yang dihasilkan \\
memiliki keunggulan rasa \\
dan tanpa bahan pengawet. \\
3. Proses produksi masih \\
sederhana sehingga rasa lebih \\
khas. \\
4. Kualitas bahan baku yang \\
bagus. \\
5. Penyediaan bahan baku yang \\
efektif dan efisien.
\end{tabular} & $\begin{array}{l}\text { KELEMAHAN } \\
\text { (WEAKNESSES) } \\
\text { 1. Lokasi usaha tidak terletak di } \\
\text { jalan utama. } \\
\text { 2. Keterbatasan suplai tenaga } \\
\text { kerja terampil. } \\
\text { 3. Ketersediaan sarana produksi } \\
\text { belum optimal. } \\
\text { 4. Kapasitas produksi masih } \\
\text { kecil. } \\
\text { 5. Promosi belum dilakukan. } \\
\text { 6. Belum memiliki outlet } \\
\text { penjualan secara khusus. }\end{array}$ \\
\hline \begin{tabular}{ll}
\multicolumn{1}{c}{ PELUANG } \\
(OPPORTUNITIES) \\
1. $\begin{array}{l}\text { Adanya dukungan kebijakan/ } \\
\text { program pemerintah bagi } \\
\text { pengembangan agroindustri. }\end{array}$ \\
2. $\begin{array}{l}\text { Selera konsumen yang } \\
\text { beragam }\end{array}$ \\
3. Keberadaan agen yang loyal. \\
4. $\begin{array}{l}\text { Budaya/kebiasaan wisatawan/ } \\
\text { masyarakat membeli oleh- } \\
\text { oleh khas daerah. } \\
\text { Pertumbuhan objek wisata } \\
\text { yang cukup pesat. } \\
\text { Pemasok yang mampu } \\
\text { menjamin ketersediaan bahan } \\
\text { baku. }\end{array}$
\end{tabular} & 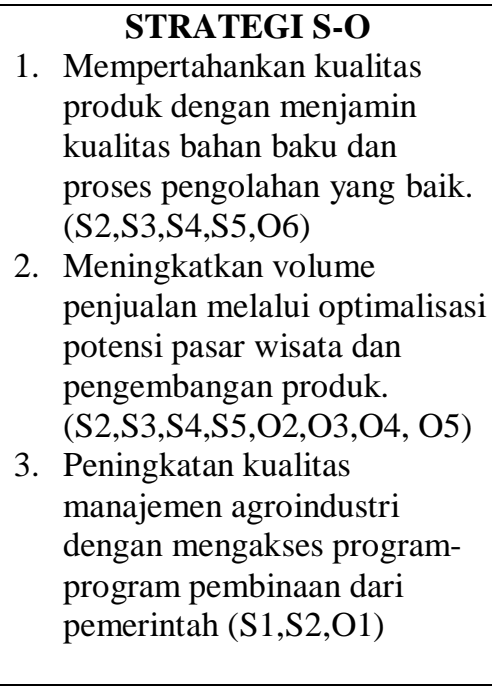 & $\begin{array}{l}\text { STRATEGI W-O } \\
\text { 1. Melakukan promosi agar } \\
\text { produk lebih dikenal } \\
\text { masyarakat } \\
\text { (W1,W5,W6,O2,O3,O4, O5) } \\
\text { 2. Melakukan investasi berupa } \\
\text { peralatan produksi untuk } \\
\text { mendorong peningkatan } \\
\text { kapasitas produksi dan } \\
\text { ketergantungan terhadap } \\
\text { tenaga kerja manusia } \\
\text { (W2,W3,W4,O1) } \\
\text { 3. Melakukan upaya pembukaan } \\
\text { outlet penjualan sehingga } \\
\text { menarik lebih banyak } \\
\text { konsumen } \\
\text { (W1,W6,O1,O3,O4,O5) }\end{array}$ \\
\hline \begin{tabular}{ll}
\multicolumn{1}{c}{ ANCAMAN } \\
$\quad($ TREATHS) \\
1. & \multicolumn{1}{c}{ Kenaikan biaya produksi. } \\
2. & $\begin{array}{l}\text { Pesaing produk agroindustri } \\
\text { sejenis. }\end{array}$ \\
3. & $\begin{array}{l}\text { Faktor musim yang } \\
\text { mempengaruhi kualitas buah } \\
\text { stroberi sebagai bahan baku } \\
\text { utama. }\end{array}$
\end{tabular} & $\begin{array}{l}\text { STRATEGI S-T } \\
\text { 1. Strategi unggul mutu } \\
\text { mempertahankan pelanggan } \\
\text { yang sudah ada, } \\
\text { meningkatkan mutu layanan } \\
\text { dan meningkatkan image atau } \\
\text { citra perusahaan di mata } \\
\text { pelanggan } \\
\text { (S2,S3,S4,T2 ) } \\
\text { 2. Melakukan pengawetan } \\
\text { bahan baku (tanpa bahan } \\
\text { kimia) sebelum musim hujan } \\
\text { untuk menjamin ketersediaan } \\
\text { bahan baku pada musim } \\
\text { penghujan } \\
\text { (S2,S4,S5,T2,T3) } \\
\text { 3. Inovasi dan diversifikasi } \\
\text { produk } \\
\text { (S1,S2,S3,S4,S5,T1,T2,T3) }\end{array}$ & 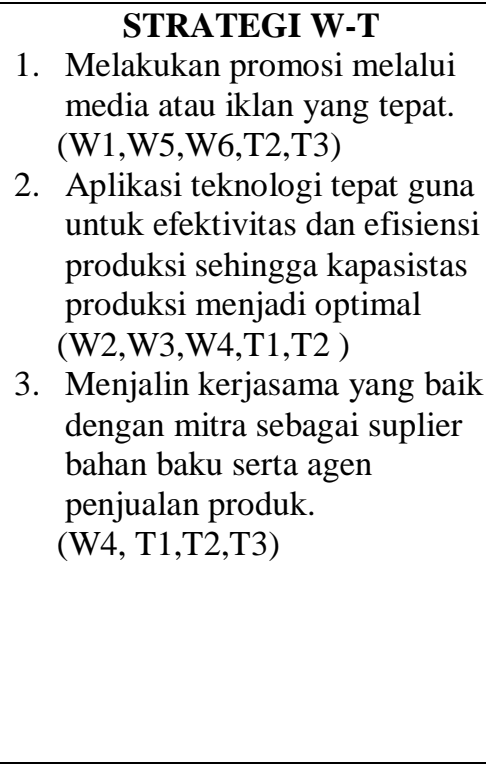 \\
\hline
\end{tabular}




\section{AIMBAR \\ Agribisnis}

ISSN 2460-4321

Volume $1 \bullet$ Nomor $2 \cdot$ Januari 2016

\section{Penentuan Prioritas Strategi Pengembangan Agroindustri Stroberi}

Penentuan prioritas strategi yang paling tepat dan utama dalam pengembangan agroindustri stroberi Kharsima, maka diperlukan suatu analisis QSPM (Quantitative Strategy PlanningMatrix). Analisis matriks ini bertujuan untuk pengembilan keputusan dari alternatif strategi yang diimplementasikan (Strategi S-O) berdasarkan analisis Matriks SWOT.

Tabel 10.Analisis QSPM (Quantitative Strategic Planning Matrix) Strategi. Pengembangan Agroindustri Stroberi "Kharisma"

\begin{tabular}{|c|c|c|c|c|c|c|}
\hline \multirow{2}{*}{$\begin{array}{c}\text { Implementasi } \\
\text { Strategi }\end{array}$} & \multicolumn{4}{|c|}{$\begin{array}{c}\text { Nilai Daya Tarik terhadap } \\
\text { Faktor Lingkungan Internal dan } \\
\text { Faktor Lingkungan Eksternal }\end{array}$} & \multirow{2}{*}{ Nilai TAS } & \multirow{2}{*}{ Prioritas } \\
\cline { 2 - 7 } & Kekuatan & Kelemahan & Peluang & Ancaman & & \\
\hline Strategi 1 & 1.454 & 0.805 & 1.485 & 0.738 & 4.482 & II \\
\hline Strategi 2 & 1.169 & 1.114 & 1.707 & 0.614 & 4.603 & I \\
\hline Strategi 3 & 1.353 & 1.030 & 1.184 & 0.614 & 4.181 & III \\
\hline
\end{tabular}

Sumber: Data Primer diolah, 2015.

Berdasarkan Tabel 11 maka dapat terlihat prioritas utama implementasi stretegi pengembangan dalam pengembangan agroindustri stroberi Kharsima, adalah pada Strategi II dengan nilai TAS sebesar 4,603 yaitu meningkatkan volume penjualan melalui optimalisasi potensi pasar wisata dan pengembangan produk.

1) Mempertahankan kualitas produk dengan menjamin kualitas bahan baku dan proses pengolahan yang baik.

Kualitas produk agroindustri stroberi "Kharisma" yang dinilai lebih unggul oleh responden merupakan akibat dari proses produksinya yang mengandalkan keterampilan tangan sehingga rasa stroberi sebagai bahan baku utama sangat terasa pada produk olahannya. Selanjutnya lokasi agroindustri "Kharisma" yang berada di kawasan sentra produksi stroberi juga mampu menjamin pasokan buah stroberi dengan kuantitas dan kualitas yang terjamin. Melihat kondisi ini maka strategi yang dapat diambil yaitu tetap mempertahankan kerjasama dengan para petani penghasil buah stroberi untuk menjamin kualitas bahan baku dan di sisi yang lain perlu melakukan pembinaan secara kontinyu kepada para pekerja tentang teknologi pengolahan serta penambahan peralatan produksi dengan kapasitas produksi yang lebih besar. Hal ini akan mengantarkan agroindustri stroberi "Kharisma" menjadi lebih efisien atau menguntungkan.
2) Meningkatkan volume penjualan melalui optimalisasi potensi pasar wisata dan pengembangan produk.

Potensi pasar yang besar karena merupakan daerah wisata harus benar-benar dimanfaatkan oleh agroindustri untuk meningkatkan penjualan. Upaya memperkenalkan produk kepada wisatawan sebagai calon konsumen harus dilakukan dengan lebih intensif dan terencana. Selain itu dalam rangka meningkatkan volume penjualan, agroindustri perlu melakukan pula pengembangan produk baik dari segi rasa maupun jenis olahan. Sehingga tidak membosankan bagi konsumen. Banyaknya konsumen juga harus dijadikan sebagai media penyampaian informasi keluar daerah sehingga lebih banyak masyarakat yang mengenal produk agroindustri stroberi "Kharisma".

3) Peningkatan kualitas manajemen agroindustri dengan mengakses programprogram pembinaan dari pemerintah.

Kebijakan pemerintah berupa program pembinaan-pembinaan, seminar, pelatihan serta pendampingan bagi UMKM di Kabupaten Bandung harus benar-benar dimanfaatkan oleh pemilik agrondustri stroberi "Kharisma" dalam upaya pengembangan usaha. Terutama pengetahuan tentang manajemen agroindustri yang baik. Kekuatan pengelola tentunya menjadi suatu keharusan dalam menghadapi persaingan yang ketat di bidang agroindustri makanan. 


\section{Strategi Pengembangan Agroindustri Stroberi CICI AULIA PERMATA BUNDA}

Dengan mengikuti berbagai pelatihan manajemen agroindustri diharapkan dapat melancarkan proses manajemen di agroindustri stroberi "Kharisma" baik fungsi perencanaan, pengorganisasian, pelaksanaan maupun pengendalian. Pada akhirnya tujuan dari agroindustri untuk mengembangkan kapasitasnya dapat tercapai dan mampu menyerap tenaga kerja lebih banyak.

\section{PENUTUP}

Berdasarkan hasil analisis dan pembahasan dapat ditarik kesimpulan sebagai berikut:

a. Faktor-faktor yang menjadi kekuatan bagi agroindustri stroberi "Kharisma" yaitu kualitas bahan baku yang bagus, produk yang dihasilkan memiliki keunggulan rasa dan tanpa bahan pengawet, sumber daya finansial (modal) sepenuhnya berasal dari perusahaan (equity capital), penyediaan bahan baku yang efektif dan efisien serta proses produksi masih sederhana sehingga rasa lebih khas.

b. Faktor-faktor yang menjadi kelemahan bagi agroindustri stroberi "Kharisma" yaitu belum memiliki outlet penjualan secara khusus, promosi belum dilakukan, keterbatasan suplai tenaga kerja terampil, lokasi usaha tidak terletak di jalan utama, ketersediaan sarana produksi belum optimal dan kapasitas produksi masih kecil.

c. Faktor-faktor yang menjadi peluang bagi agroindustri stroberi "Kharisma" yaitu pertumbuhan objek wisata yang cukup pesat, selera konsumen yang beragam, pemasok yang mampu menjamin ketersediaan bahan baku, adanya dukungan kebijakan atau program pemerintah bagi pengembangan agroindustri, keberadaan agen yang loyal dan budaya atau kebiasaan wisatawan atau masyarakat membeli oleh-oleh khas daerah.

d. Faktor-faktor yang menjadi ancaman bagi agroindustri stroberi "Kharisma" yaitu pesaing produk agroindustri sejenis, kenaikan biaya produksi dan faktor musim yang mempengaruhi kualitas buah stroberi sebagai bahan baku.

e. Strategi yang paling tepat dalam upaya pengembangan agroindustri stroberi "Kharisma" adalah strategi S-O (StrengthsOpportunities)yaitu dengan meningkatkan volume penjualan melalui optimalisasi potensi pasar wisata dan pengembangan produk.

\section{DAFTAR PUSTAKA}

Badan Pusat Statistik Kabupaten Bandung 2011. Kabupaten Bandung dalam Angka Tahun 2010. Badan Pusat Statistik Kabupaten Bandung.

Freddy Rangkuti. 2000. Analisis SWOT: Teknik Membedah Kasus Bisnis. Cara Perhitungan Bobot, rating dan OCAI. PT Gramedia Pustaka Utama. Jakarta.

Freddy Rangkuti. 2009. Analisis SWOT. Teknik Membedah Kasus Bisnis. Reorientasi Konsep Perencanaan Strategis untuk Menghadapi Abad 21. PT.Gramedia Pustaka Utama. Jakarta.

Moehar Daniel. 2002. Pengantar Ekonomi Pertanian. PT Bumi Aksara. Jakarta.

Rahmat Rukmana. 1998. Stroberi Budidaya dan Pascapanen. Kanisius. Yogyakarta.

Soekartawi. 1995. Analisis Usahatani. Universitas Indonesia. Jakarta.

Soekartawi. 2001. Pengantar Agroindustri. PT Raja Grafindo Persada. Jakarta.

Supriatin Budiman dan Desi Saraswati. 2008. Berkebun Stroberi Secara Komersial. Penebar Swadaya. Jakarta.

Supriyati dan Suryani E. 2006. Peranan, Peluang dan Kendala Pengembangan Agroindustri di Indonesia. Forum Penelitian Agro Ekonomi. Volume 24 No 2, Desember 2006: 92-106 


\section{AIMBAR Agribisnis}

ISSN 2460-4321

Volume 1・Nomor 2・Januari 2016 